\title{
Depositional model for mud-diapir controlled intra-slope basins, deepwater Niger delta, Nigeria
}

\author{
E. K. Nyantakyi ${ }^{1,2} \cdot$ Tao $\mathrm{Li}^{1} \cdot$ Wangshui $\mathrm{Hu}^{1}$ • \\ J. K. Borkloe ${ }^{1,2}$
}

Received: 30 September 2014/ Accepted: 24 May 2015/Published online: 12 June 2015

(C) Akadémiai Kiadó 2015

\begin{abstract}
The study investigated depositional model for mud-diapir controlled intra-slope basins, deepwater Niger delta, Nigeria using conventional 3D seismic data and an enhanced detection of geologic events volume. The results of the study revealed three types of seismic facies namely accretionary channel, distributary channel and lobe and drape complexes. Channels varied in both morphology and associated depositional elements and their sinuosity was found to generally reduce with decreasing age of occurrence. Six different types of reservoir elements were identified in the study area. Three reservoir elements were associated with the channel axis and the other three elements were associated with sheet deposits. Knowledge of these variations as well as identification of the different elements is necessary to a successful exploration and development plan. The depositional model generated for the study area showed repeatable and cyclic depositional processes involved in sedimentation in this type of basin. The ideal major depositional cycle was made up of mass transport deposits at the base, overlain by a distributary channel and lobe complex, overlain by an amalgamated channel complex, and capped by a drape complex. A modified depositional model referred to as the deflect-model applies to shale-diapir sub-basins in Nigeria.
\end{abstract}

Keywords Depositional model $\cdot$ Mud-diapir $\cdot$ Intra-slope basin $\cdot$ Deepwater $\cdot$ Niger delta

\section{Introduction}

Recently, various workers both in industry and academia have concentrated on studying deep-water stratigraphy, depositional elements, turbidite deposition, reservoir types and architecture, and channel patterns. Efforts include those of Beaubouef et al. (1998, 2000),

Wangshui $\mathrm{Hu}$

huwangshui@126.com

1 School of Geosciences, Yangtze University, No.1 University Road, Caidian Wuhan 430100, Hubei, China

2 Civil Engineering Department, Kumasi Polytechnic, P.O. Box 854, Kumasi 00233-03220, Ghana 
Posamentier and Kolla (2003), Edith et al. (2005), Badalini et al. (2000), Posamentier et al. (2000), Weimer et al. (1995, Weimer and Slatt 2004), Prather et al. (1998), Mayall (2000), Pirmez et al. (2000), Clark and Pickering (1996), Booth et al. (2000), Demyttenaere (2000), Brami (2000), Gardner et al. (2003), Adeogba et al. (2005), and McHargue (1991). These and other relevant studies have led to the development of the fill and spill model for salt withdrawal intra-slope basins in the Gulf of Mexico, facies associations and stacking patterns in the deep-water system, deep-water depositional elements and their associations, and submarine fan types and architecture.

Prather et al. (1998) examined the filling process of the Gulf of Mexico intra-slope basins, studied facies associations and stacking patterns in this system, and recognized $\mathrm{A}$, $\mathrm{Bh}, \mathrm{Bl}, \mathrm{Cbh}, \mathrm{Cbl}, \mathrm{Cth}, \mathrm{Ctl}, \mathrm{D}$ and $\mathrm{E}$ facies based on seismic characters and internal event geometry. Beaubouef and Friedman (2000) described the filling process and seismic facies associations in the western Gulf of Mexico Pleistocene intra-slope basins. They interpreted the stacking pattern of seismic facies in the deep-water setting. They also examined seismic facies cyclicity of alternating deposits in the following order from bottom to top: mass transport complexes (MTCs), distributary channel and lobe complexes, levee channel complexes, and drape complexes. Badalini et al. (2000) examined the filling process as well as the stratigraphy and seismic facies succession in the late Pleistocene Brazos-Trinity turbidite system, Gulf of Mexico continental slope. Pirmez et al. (2000) studied a variety of submarine channels, processes that disrupt their equilibrium profile, and the effects of such disruptions on the architecture of deepwater reservoirs. Posamentier and Kolla (2003), in their study of deep-water settings, identified five depositional elements and described the architecture of associated deposits. Booth et al. (2000) looked at the link between eustatic cycles, depositional processes, accommodation space, and resulting deposits for the Auger basin, central Gulf of Mexico slope. Sullivan et al. (2000) used outcrops for reservoir architectural analysis. They used this to bridge the gap in both scale and resolution between seismic and well-bore data. Clark and Pickering (1996) examined the architectural elements and growth pattern of submarine channels and the characteristics of associated deposits. Gardner et al. (2003) studied the process response model for a submarine channel-lobe system using the Brushy Canyon outcrop. They examined the cause and effect of lateral migration of channel lobe systems through time. All of these studies, among others, have contributed to the understanding of deep-water depositional systems from the slope to basin floor.

A number of workers, especially in the oil and gas industry, have worked in the Niger delta deep water both on stratigraphy and structure. The Niger delta has been sub-divided into seven depositional centers, referred to as depobelts, based on the age of their associated paralic sequence and the age of the alluvial sands that cap the paralic sequence (Doust and Omatsola 1990). The onshore to shelf region has six subdivisions: northern delta, greater Ughelli, central swamp I, central swamp II, coastal swamp I, and coastal swamp II. The depobelts are either NE-SW or NW-SE trending. The interplay of subsidence and sediment supply resulted in discrete depobelts. When further crustal subsidence of the basin could no longer be accommodated, the site of sediment deposition shifted seaward to form a new depobelt (Doust and Omatsola 1990). Each depobelt is known as a mega-structure, and it is separated from the next by major structural building, regional and/ or counter-regional faults (Evamy et al. 1978). The offshore portion is the seventh depobelt. Each cycle (depobelt) is 30-60 km wide and progrades southwestward about $250 \mathrm{~km}$ over oceanic crust into the Gulf of Guinea (Stacher 1995) and has its own sedimentation, deformation and petroleum history. 


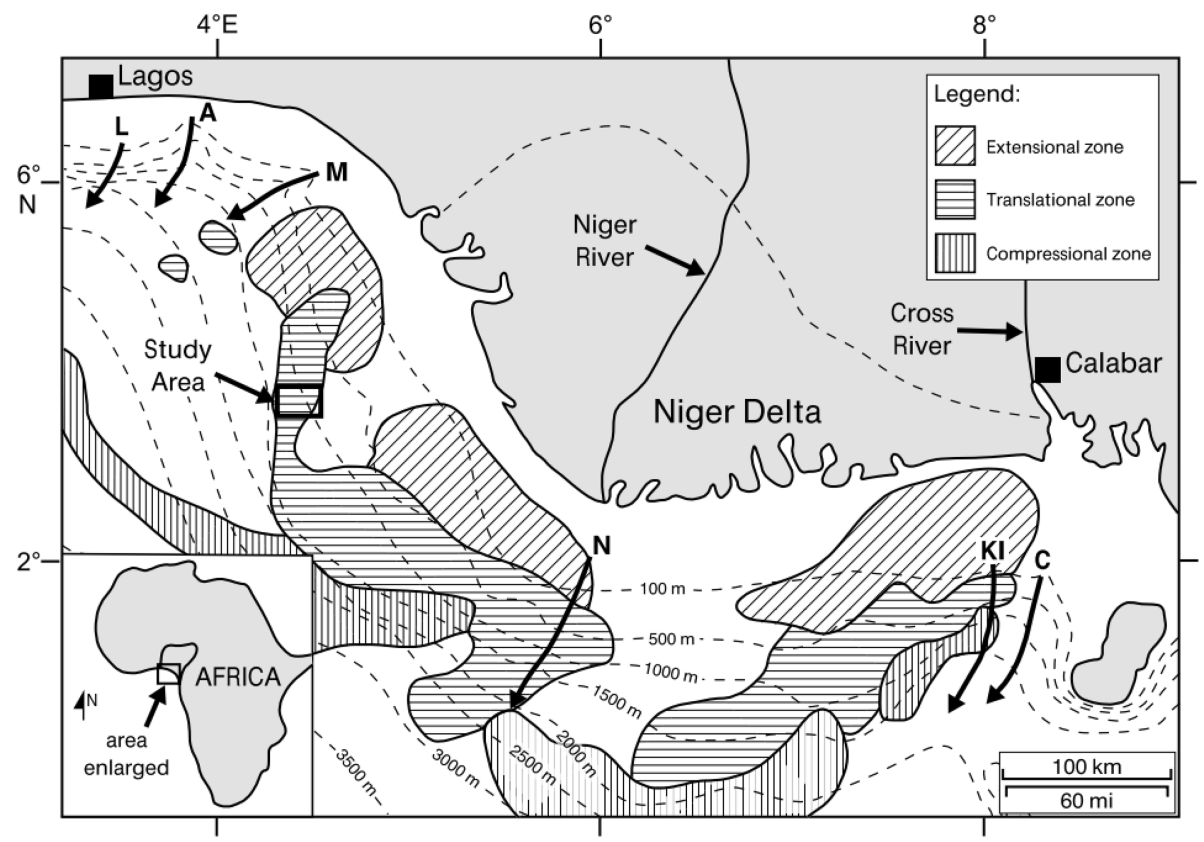

Fig. 1 Niger delta basin showing bathymetry, zones of gravity tectonic structural style and modern submarine canyons (modified after Knox and Omatsola 1989; Damuth 1994). Thick arrows show submarine canyons. $L$ Lagos, A Avon, $M$ Mahin, $N$ Niger, $K I$ Kwa-Ibo and $C$ Calabar. The study area is shown

The study area is located in the offshore part of these sub-divisions. Damuth (1994) subdivided the delta into three tectonic zones: (1) extensional, (2) translational, and (3) compressional (Fig. 1). The study area falls within the translational zone of this division, and consists of structures such as compressional mud or shale diapirs and extensional faults that underwent some inversion at depth due to movement on the shale ridges. Mitchum et al. (1991) examined tectonic controls on Niger delta regional deep-water stratigraphy and subdivided the entire delta into three tectonic settings: (1) shelf areas, (2) diapiric slope areas, and (3) compressive toe thrusts in near- and far-distal basin regions. Corredor et al. (2005) further subdivided the delta into five tectonic zones with emphasis on the structural styles in the deep-water fold and thrust belts of the Niger delta. This study area falls within the mud diapir zone of this division. In the work of Adeogba et al. (2005), on the Niger delta slope, they identified seismic facies in the study area to include mass transport complexes, distributary channel and lobe complexes, and drape complexes. They interpreted distributary channel and lobe complexes as the sandy reservoir facies in this system. They attributed the lack of leveed channel complexes in this area to the lack of fine-grained sediment in building levees and interpreted nick-points development and migration for the shallow near-surface interval. The advantage in the study is that stratigraphic and seismic facies analysis will show that growth of mud diapirs causes depositional axes to change. This is due to the semi-circular nature of the intra-slope basins, which is different from what has been documented for salt-withdrawal basins, known to be usually bowl-shaped. Furthermore, depositional model generated for this intra-slope basin and controlled by mud diapirs will show a different filling history from that of salt-diapir controlled intra-slope basins of the Gulf of Mexico. The model developed for salt-diapir basins is "fill and spill; 
while that of mud-diapir basins as revealed by this study appears to be 'fill, spill and deflect', in which the main axis of deposition changes instead of bypassing over filled minibasins as is the case with salt-withdrawal basins. It is in the light of the above that the study investigated depositional model for mud-diapir controlled intra-slope basins, deepwater Niger delta, in Nigeria using conventional 3D seismic data and an enhanced detection of geologic events volume. Figure 1 shows the Niger delta basin showing bathymetry, zones of gravity tectonic structural style and modern submarine canyons.

\subsection{Basin geology}

The Niger delta is one of the world's largest deltaic systems. The delta covers an approximate area of about $300,000 \mathrm{~km}^{2}$ (Kulke 1995), with sediment volume of $500,000 \mathrm{~km}^{3}$ (Hospers 1965) and sediment thickness ranging between 9000 and 12,000 m. The delta extends more than $300 \mathrm{~km}$ from apex to mouth (Doust and Omatsola 1990). Galloway (1975) classified the Niger delta as a wave- dominated tidal-influenced delta. The Niger delta is bounded to the north by the Anambra basin, to the west by the Okitipupa high and the Benin flank, and to the east by the volcanic rocks of the Cameroon volcanic zone. There was an original paleo-high that separated the eastern from the western delta, but that has since been covered with sediments.

The Niger delta is an overall regressive sequence (Fig. 2) formed by an interplay between the rate of deposition or sediment supply and the rate of subsidence or accommodation space creation. For this delta, the rate of deposition far exceeded the rate of subsidence, which resulted in an overall progradational delta (Knox and Omatsola 1989). Major submarine canyons delivered sediments from the shelf edge into the deep-water environment.

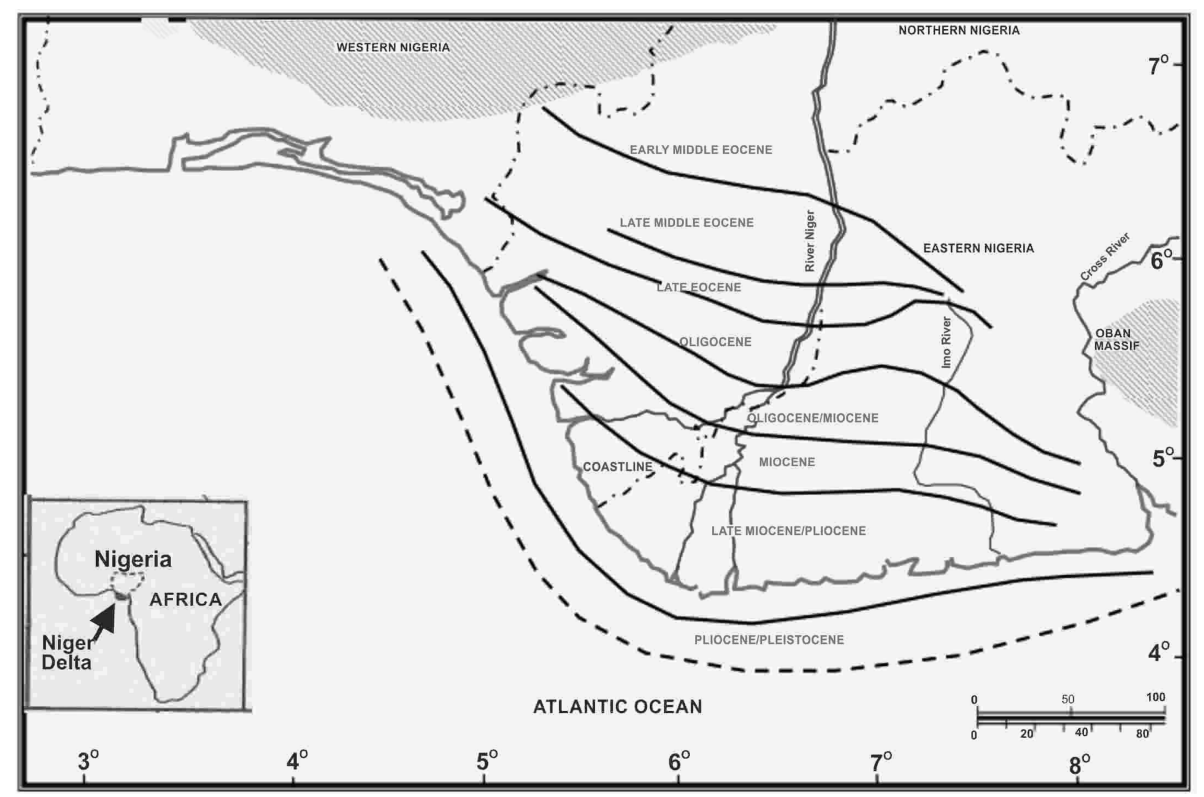

Fig. 2 Niger delta basin and its stages of development (modified after Short and Stauble 1967) 
The study area on the Niger delta slope is located about $130 \mathrm{~km}$ offshore and at a water depth varying from 1300 to $1500 \mathrm{~m}$. The area falls within the mud diapir zone beneath the upper continental slope, which is defined by passive, active and reactive mud diapirs (Morley and Guerin 1996; Corredor et al. 2005) and the translational zone of Damuth (1994). The study area is characterized by shale ridges and massifs, shale overhangs and vertical mud diapirs that form mud volcanos at the sea floor and interdiapir sub-basins (Graue 2000; Corredor et al. 2005). Mobility of shale had induced internal deformation which had occurred as a result of two processes (Kulke 1995). First, shale diapirs had been formed from loading of poorly compacted, over-pressured, prodelta and delta-slope clays (Akata Formation) by the higher density delta-front sands (Agbada Formation). Second, slope instability had occurred due to a lack of lateral, basinward support for the undercompacted delta-slope clays (Akata Formation) (Fig. 3). For any given depobelt, gravity tectonics were completed before deposition of the Benin Formation and are expressed in complex structures, including shale diapirs, roll-over anticlines, collapsed growth fault crests, back-to-back features, and steeply dipping, closely spaced flank faults (Evamy et al. 1978; Xiao and Suppe 1992). These faults mostly offset different parts of the Agbada Formation and flatten into detachment planes near the top of the Akata Formation. The Niger delta intra-slope basins are slightly different from the well-studied salt-withdrawal basins of the Gulf of Mexico continental slope. While the salt withdrawal basins are threedimensional, bowl-shaped, closed basins, the shale diapir controlled intra-slope basins of the Niger delta occur in a semi-circular form (Fig. 4). Therefore, the fill and spill model

\section{Distal Portion of Depobelt}

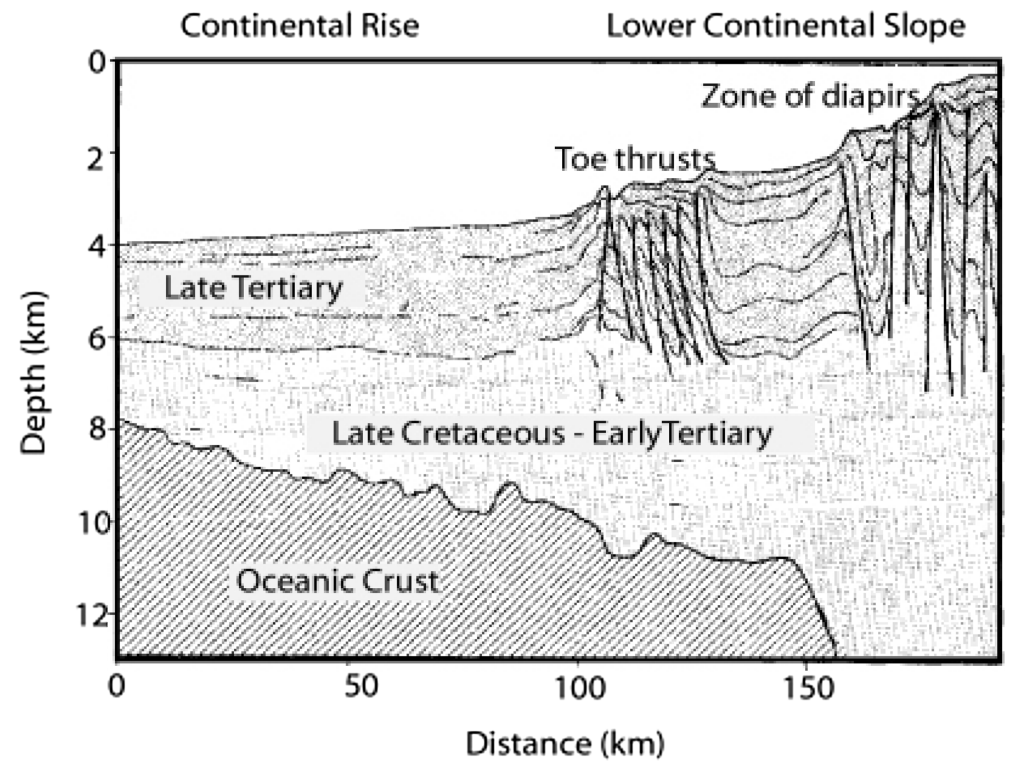

Fig. 3 Schematic of a seismic section from the Niger delta continental slope/rise showing the results of internal gravity tectonics on sediments at the distal portion of the depobelt. The Late Cretaceous-early Tertiary section has a low-velocity gradient, probably marine shales, whereas the Late Tertiary has a normal-velocity gradient, suggesting a much sandier facies. Modified from Lehner and De Ruiter (1977) and Doust and Omatsola (1990) 


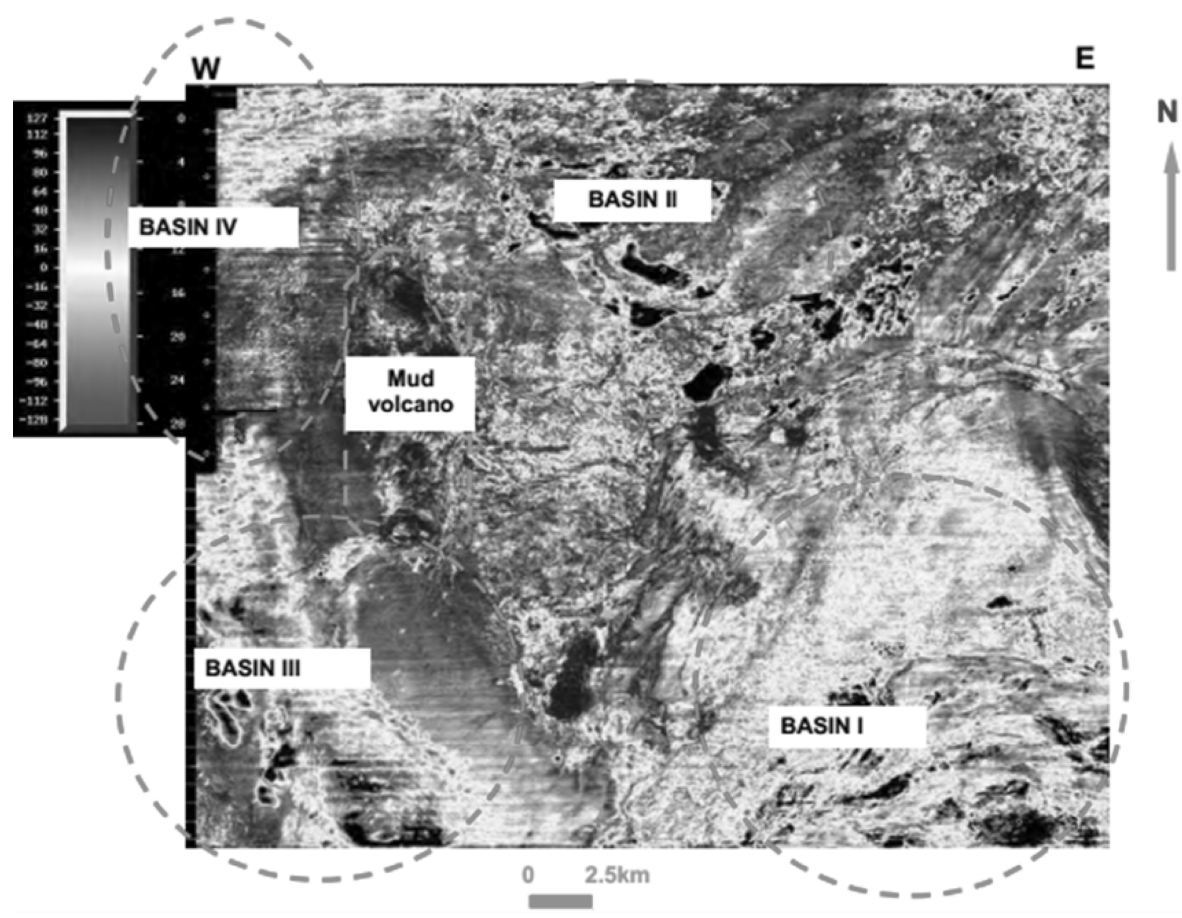

Fig. 4 RMS amplitude map over the study area showing locations of mini-basins. Proportional slices were generated every 15-20 ms using the interpreted horizons and isochron maps. Although these proportional horizons do not necessarily follow seismic reflections, they mimic structural geometry between the parent horizons and were used to study geologic features between interpreted levels

developed for the mini basins of the Gulf of Mexico continental slope must be modified for the growth history of the Niger delta intra-slope basin and other basins with similar tectonic setting. Based on differential ponded-basin accommodation space (Prather et al. 1998) and separate filling history, the study area is sub-divided into four sub-basins. Basin I is located at the southeast, Basin II at the center, Basin III at the southwest, and Basin IV at the northwestern region of the study area (Fig. 4). The four basins are separated mainly by topographic relief created by mud diapirs and are linked by a network of channels.

\subsection{Stratigraphic setting}

Short and Stauble (1967) have subdivided the recent Niger delta into three lithostratigraphic units, ranging in age from Paleocene to Recent. They are the Akata, Agbada, and Benin Formations, from bottom to top. This sequence exhibits a very strong diachronous relationship (Fig. 5). The type sections are described in detail in Short and Stauble (1967).

\subsubsection{Akata Formation}

The Akata Formation is located at the base of the Niger delta sequence and consists of prodelta, hemipelagic, and pelagic shales deposited in marine environments. Thick shales (potential source rocks), turbidite sandstones (potential deep-water reservoirs), and some 


\section{SW Stratigraphy NE}

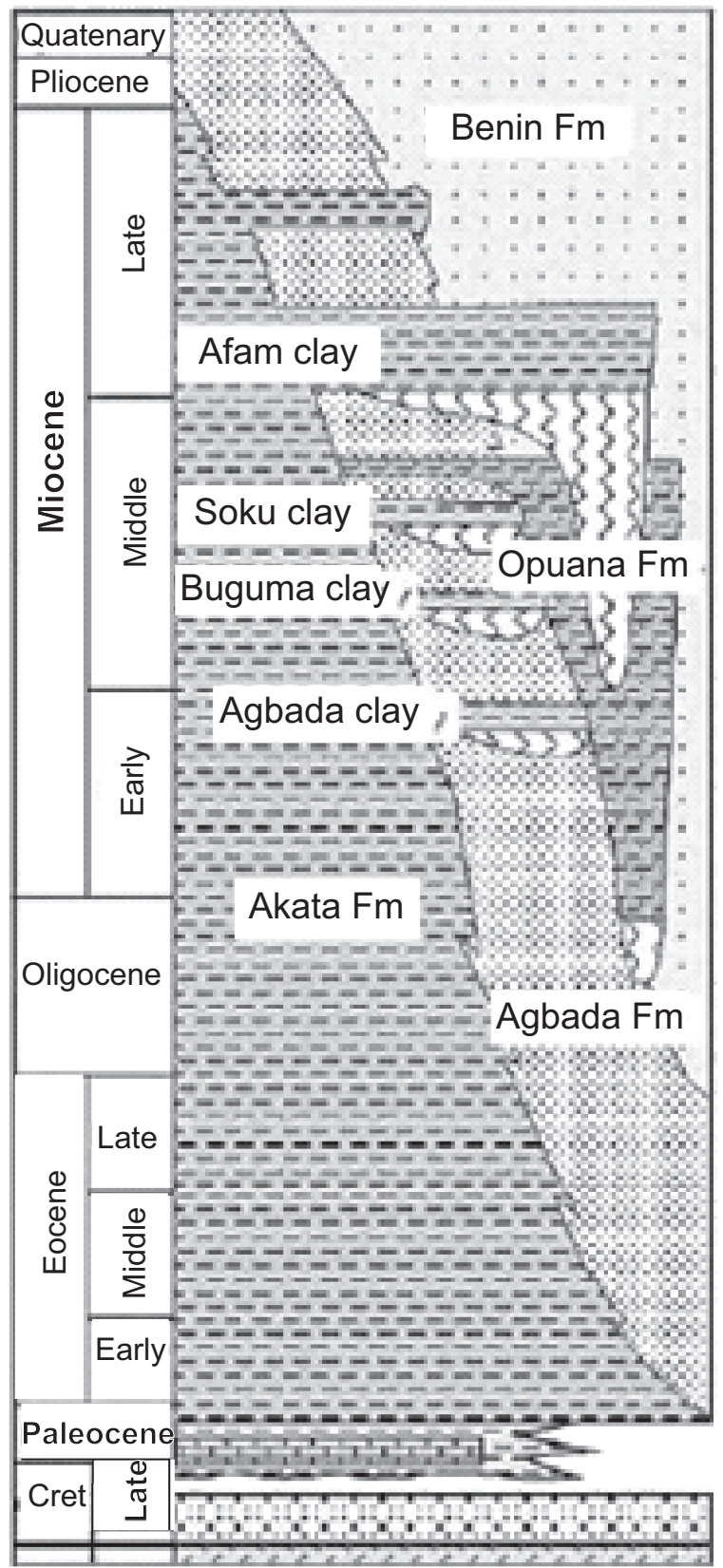

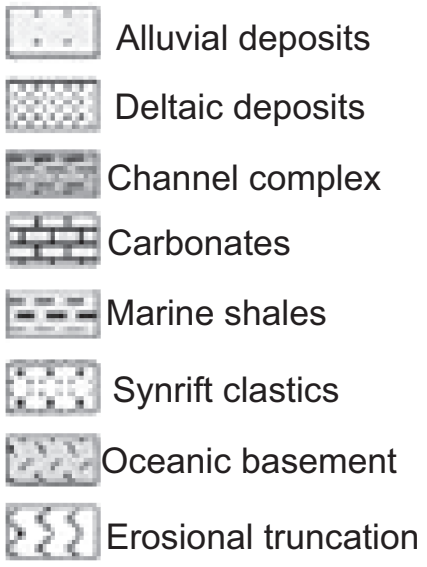

Fig. 5 Schematic diagram of the regional stratigraphy of the Niger Delta

clays and siltstones were deposited during lowstands when these materials were transported to deep-water areas that were characterized by low-energy, anoxic conditions (Stacher 1995). The formation is Late Paleocene to Recent in age. The Akata is 
characterized by high plasticity and overpressures, especially at depth. All major structural building faults and counter-regional faults merge onto a plane at the lower part of this formation (Corredor et al. 2005). The thickness of the Akata Formation ranges from $2000 \mathrm{~m}$ at the most distal part to $7000 \mathrm{~m}$ beneath the continental shelf (Doust and Omatsola 1990). The Akata exhibits low P-wave seismic velocities of about $2000 \mathrm{~m} / \mathrm{s}$ (Corredor et al. 2005) and is generally represented by low-impedance reflectors with some parts of a seismic section being transparent.

\subsubsection{Agbada Formation}

The Agbada Formation comprises a paralic sequence of interbedded sandstones and shales. This represents the actual deltaic portion of the sequence. The sandstones were deposited in prograding transitional or coastal environments that consisted of lagoon, brackish water, bay, beach, shoreface, fluvio-deltaic and barrier islands of a delta front, delta topset and fluvio-deltaic environments. The shale interbeds are prodelta to hemipelagic in origin. The Agbada Formation is Eocene to Recent in age and about $3500 \mathrm{~m}$ thick. Most of the hydrocarbon accumulations on the shelfal portion of the Niger delta have been found in this formation. The paralic nature of the Agbada Formation is a reflection of the local relative sea-level fluctuations, variation in sediment influx and differential subsidence. Sand percentage varies from up to $75 \%$ in the upper part to less than $50 \%$ in the lower part (Short and Stauble 1967). This is due to a progressive, irregular basinward advancement of the delta.

\subsubsection{Benin Formation}

The uppermost unit of the Niger delta sequence, the Benin Formation, is mainly arenaceous and consists of marginal-marine to continental sandstones deposited in fluvial to coastal environments. The environment of deposition includes braided streams and meander-belt systems of the continental upper delta plain. The formation ranges in age from Oligocene to Recent, although the lack of fauna has made direct age dating somewhat difficult (Doust and Omatsola 1990). This formation has a very high sand percentage (70-100 \%) with very few minor shale interbeds. The shares are deficient in characteristic marine or brackish-water microfauna. The thickness is variable and could be more than $2000 \mathrm{~m}$ (Short and Stauble 1967). To date, very few hydrocarbon accumulations have been discovered in the Benin formation.

\section{Methodology}

The dataset for this research is a conventional 3D seismic data and EDGE ${ }^{\mathrm{TM}}$ volume. The $3 \mathrm{D}$ seismic data has a $-90^{\circ}$ phase and a dominant frequency of $60 \mathrm{hz}$. $\mathrm{EDGE}^{\mathrm{TM}}$, otherwise known as enhanced detection of geologic events, is a Chevron proprietary version of the more popular coherency volume that transforms the amplitude cube into a difference cube. It is different from coherency in that while the latter is based on trace to-trace-correlation, the former is based on trace-to-trace differences. EDGE ${ }^{\mathrm{TM}}$ processing has become very useful in structural interpretation to define fault geometry and continuity, and in seismic stratigraphic interpretation to define channel forms and fan geometries. The survey covers about $500 \mathrm{~km}^{2}$ and spacing between lines is $12.5 \mathrm{~m}$ in both inline and cross line directions. 


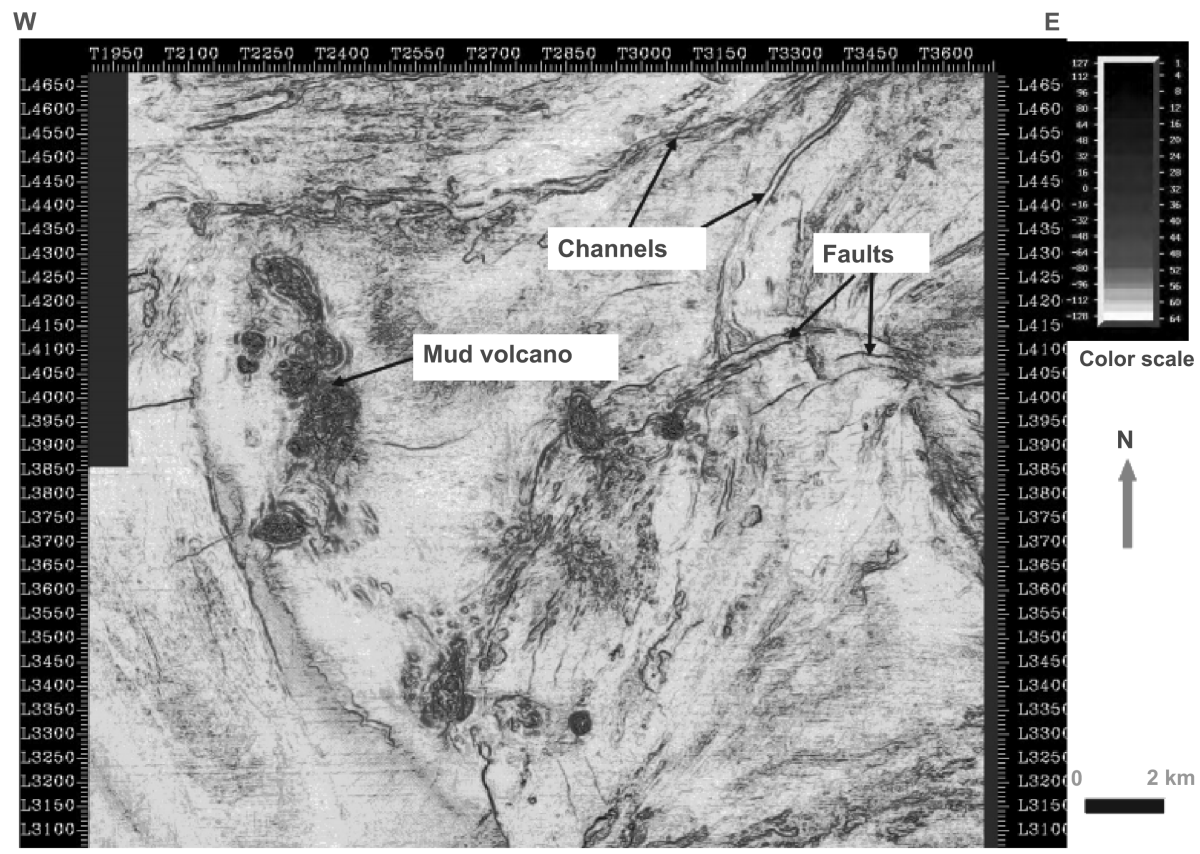

Fig. 6 Horizon slice $40 \mathrm{~ms}$ above datum 1 using EDGE volume shows distinctive channel and fault pattern, and mud volcano

These are oriented east-west and north-south, respectively. The thickness of the study interval ranges from $1000 \mathrm{~ms}(\sim 1000 \mathrm{~m})$ in the northern part to $1200 \mathrm{~ms}(1200 \mathrm{~m})$ in the southern sub-basins. The time interval is generally between 1300 and $2500 \mathrm{~ms}$. Seismic events are generally continuous with high amplitudes in shallow intervals (1300 and $1800 \mathrm{~ms}$ ). Below $1800 \mathrm{~ms}$, the seismic quality is not as good and reflectors are less continuous due to the presence of shale ridges and mud diapirs.

The conventional 3D seismic data and an $\mathrm{EDGE}^{\mathrm{TM}}$ volume was used to interpret depositional processes, stratigraphy and facies distribution for mud-diapir controlled intra-slope basins, deepwater Niger delta, Nigeria. Seismic facies and stratigraphic evolution were determined from seismic character including reflection configuration, termination pattern, reflection strength and continuity. Horizons and faults were interpreted and $\mathrm{EDGE}^{\mathrm{TM}}$ (enhanced detection of geologic events) volume was used to study channel pattern evolution and structural geometry (Figs. 6, 7). Channel morphology and evolution were related to depositional processes and eventual distribution of depositional elements and facies. Seismic event terminations were analyzed to study growth strata. Flattened seismic horizons were used to study the stratigraphic evolution of the area. Root mean square seismic amplitude extraction was used to study the evolution and distribution of reservoir facies. 


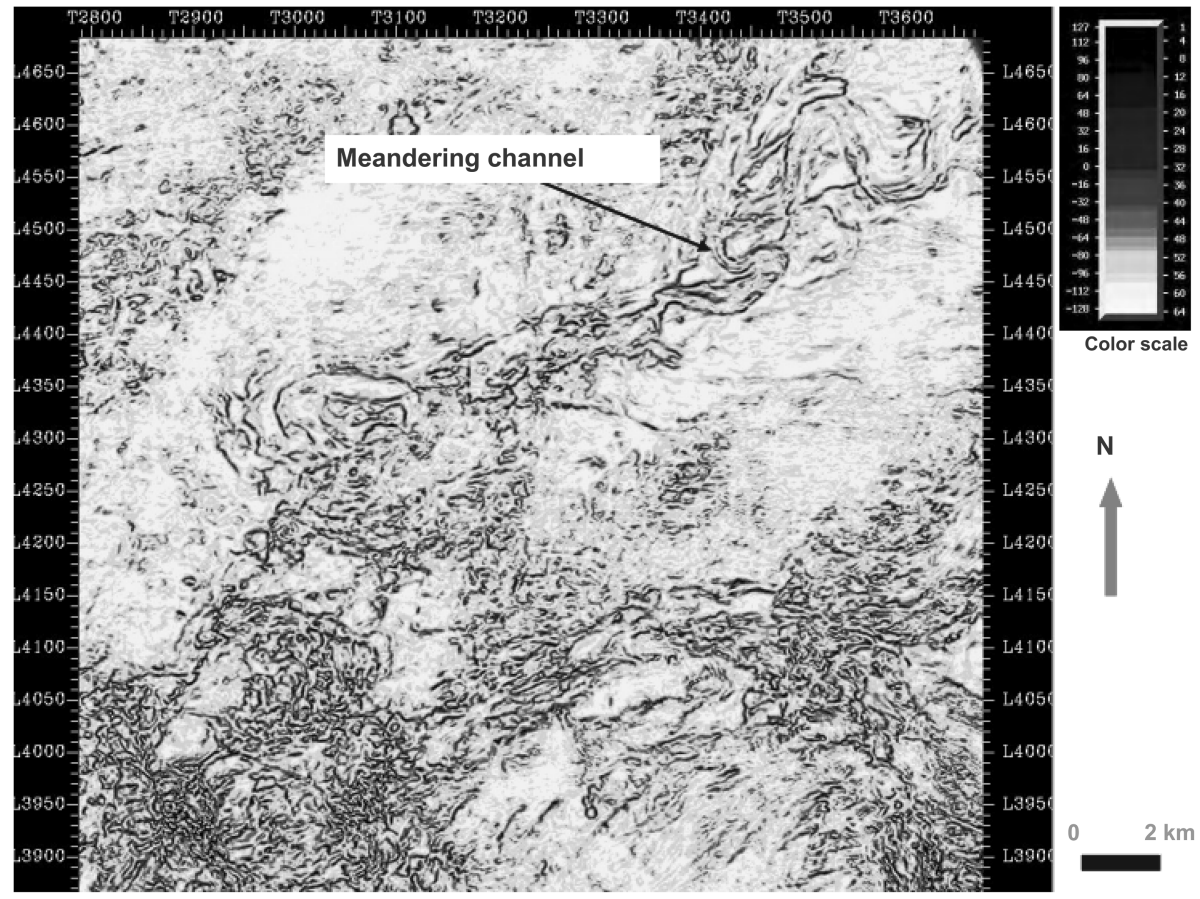

Fig. 7 Horizon slice $70 \mathrm{~ms}$ below datum 5 on EDGE volume shows a meandering channel

\section{Results and discussions}

\subsection{Depositional model}

Strata termination patterns on seismic sections, reservoir facies distributions provided information in constructing a depositional model for mud-diapir controlled intra-slope basins, offshore Niger delta, Nigeria. In this model, there are four stages involved in generating a complete genetically related stratigraphic unit.

Figure 8 represents the 'partial confinement stage'. This is a period when there was enough partial confinement in Basin I to allow for some sediment accumulation. Sediments trapped in this space consisted of a small volume of mass transport complexes (MTC) from a more proximal basin, overlain by distributary lobe complexes in the distal portion and amalgamated channel complexes in the more proximal end. There is also a variable amount of shale drape on top of the flow element, or what can be called a 'depositional unit'.

The partial confinement stage is followed by a stage of spilling referred to as the "spill stage'. During the spill stage (Fig. 9), the remaining partially confined space was filled to spill point and bypassed to an outboard basin to start a new depositional unit. The implication is that depositional units, with the exception of widely distributed drape complexes (DCs), are not correlatable across many intra-slope basins because they are not continuous. Lithologically, the partial confinement stage is entirely made up of mass transport deposits of variable lithology in the proximal basin and the partially confined facies of an outboard basin. 


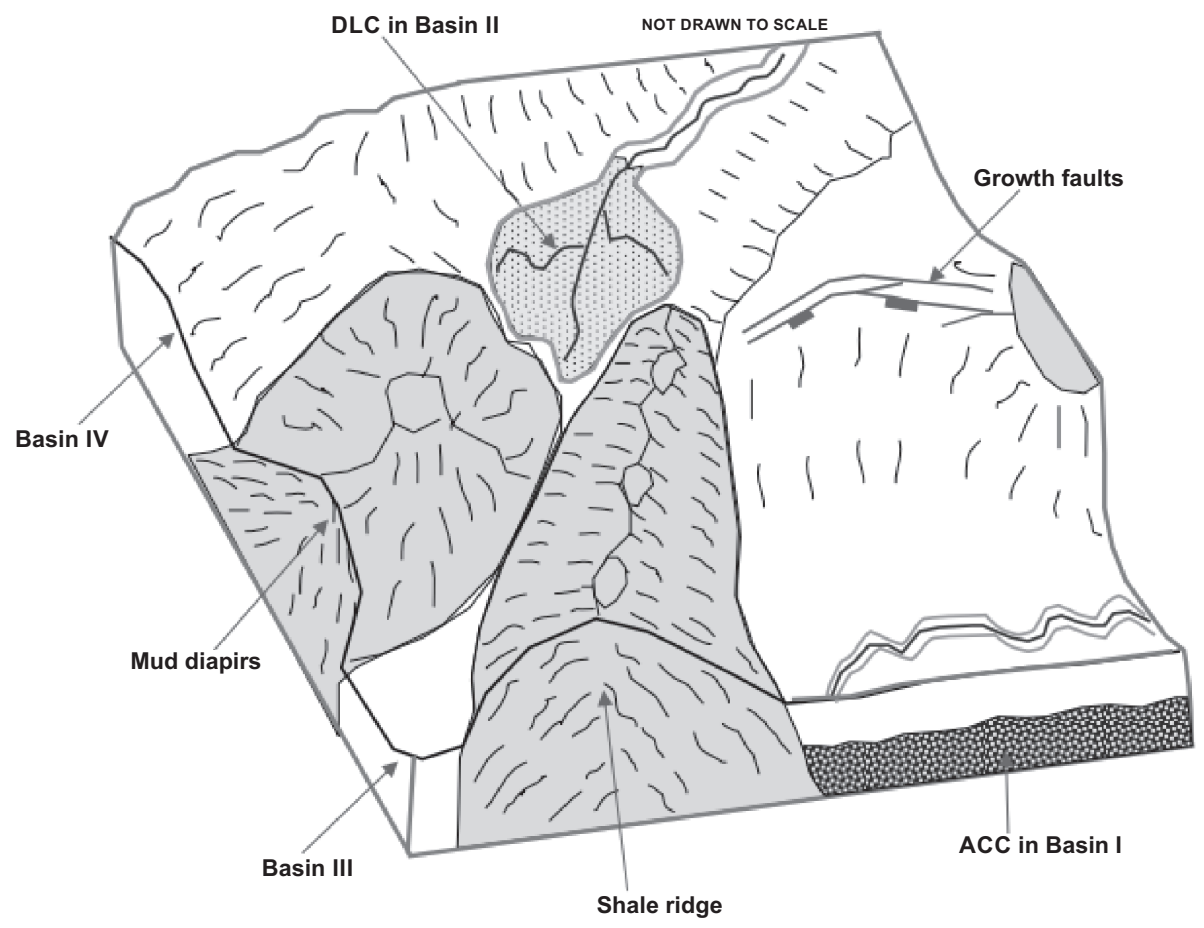

Fig. 8 Idealized diagram of partial confinement stage of depositional model of deepwater Niger delta

The spill stage is directly followed by the 'growth stage'. During the growth stage (Fig. 10), the rate of growth on the mud diapirs was far higher than sedimentation rate, which actually tends to zero. There are two possible reasons for the more obvious growth on the diapirs. First, it could be due to the mud diapirs growing at a faster rate than the preceding period of time, or it could be that the rate of growth of the diapirs was constant, whereas the rate of sediment influx was extremely low. This allowed the growth of the diapirs to be more fully expressed than earlier in the cycle. The latter scenario seems more likely, and this is interpreted as a period of depositional quiescence which could be due to a rise in relative sea level, channel avulsion in the upper part of the slope, or a drastic reduction in sediment influx. During this period, the amount and size of sediment getting into the basin was so small that the rate of growth on the diapirs was far higher than sedimentation rate. This re-created partial confinement in the proximal part of the structural high. The acronym 'growth stage' does not imply that there is no growth on the mud diapirs during the earlier and later stages of deposition.

During the growth stage, there is a continuous deposition of drape facies on earlier sediments. It only means that the rate of growth of mud diapirs far exceeded the rate of sedimentation. The lateral extent and thickness of the capping drape facies depended on the duration of sediment starvation and the amount of clay-sized materials brought into the basin.

The last stage (Figs. 11a, b) in the evolution is called the 'deflect stage'. This represented a stage when there was more or renewed partial confinement in the proximal basin, 


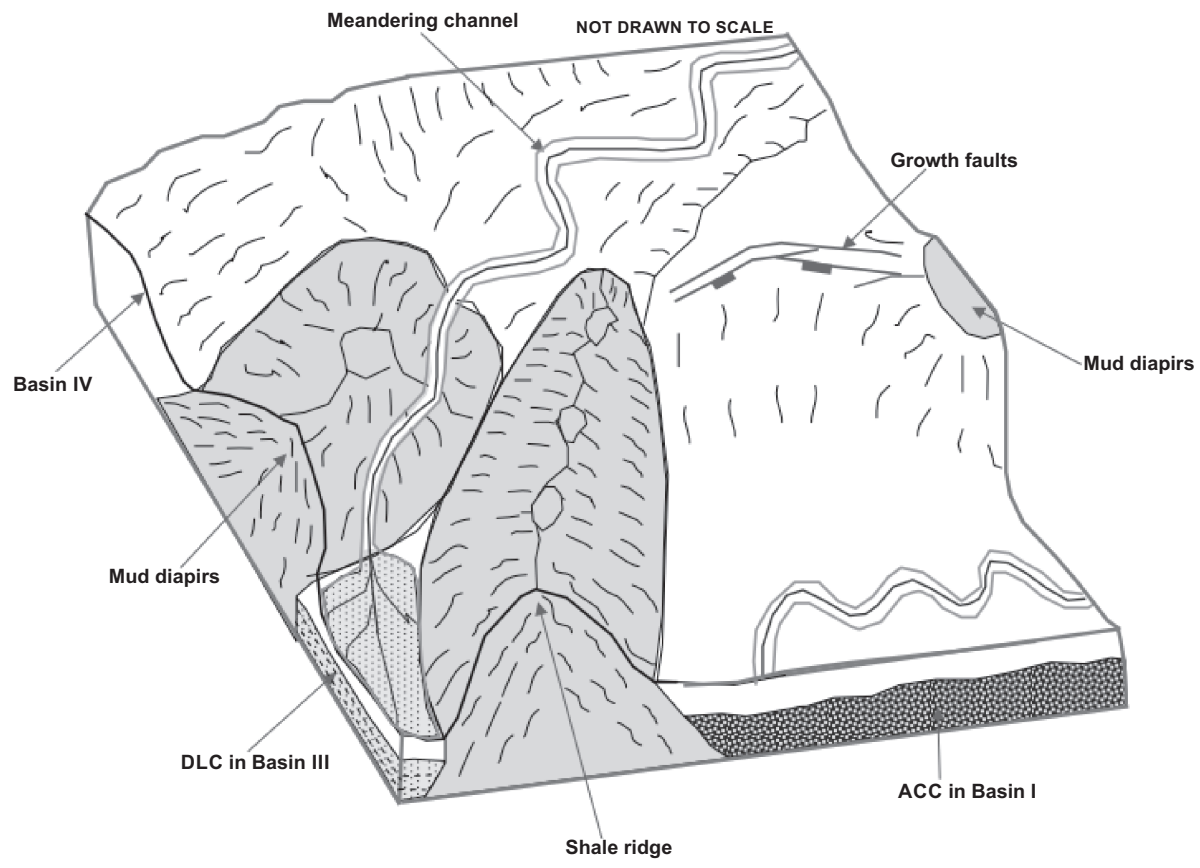

Fig. 9 Idealized diagram of spill stage of depositional model of deepwater Niger delta

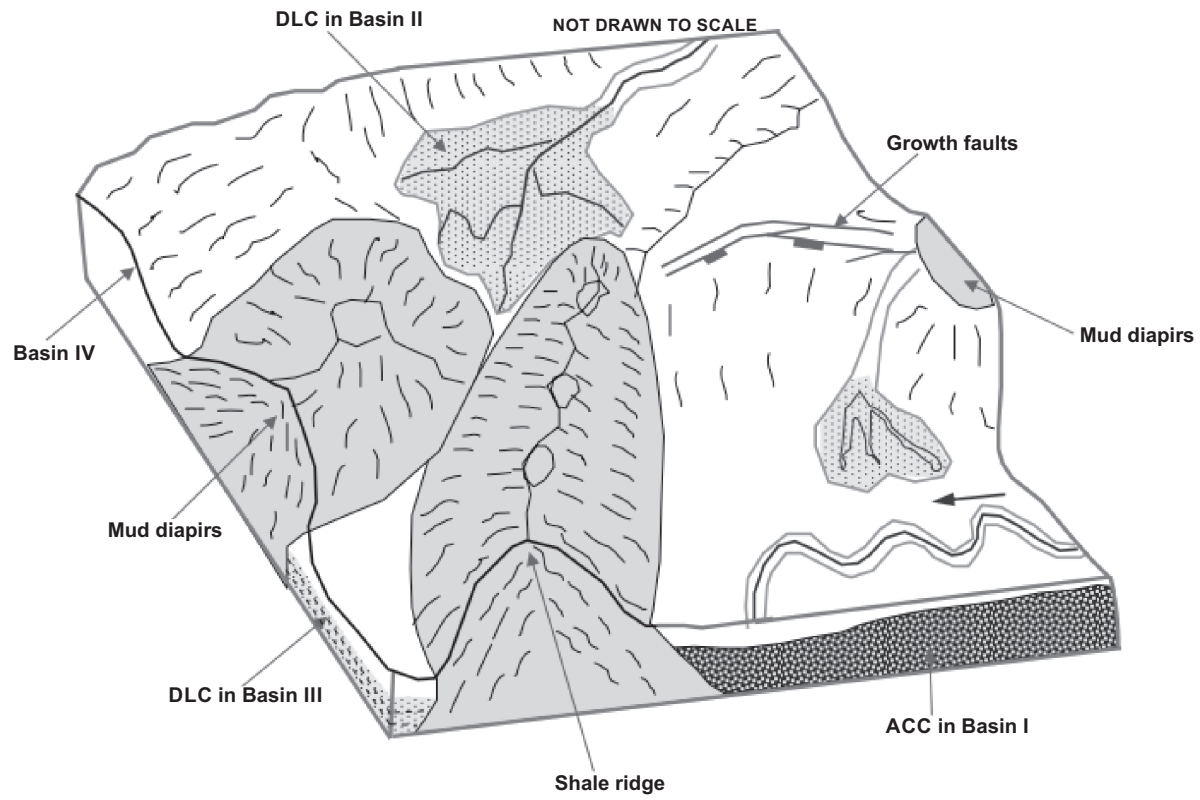

Fig. 10 Idealized diagram of growth stage of depositional model of deepwater Niger delta 

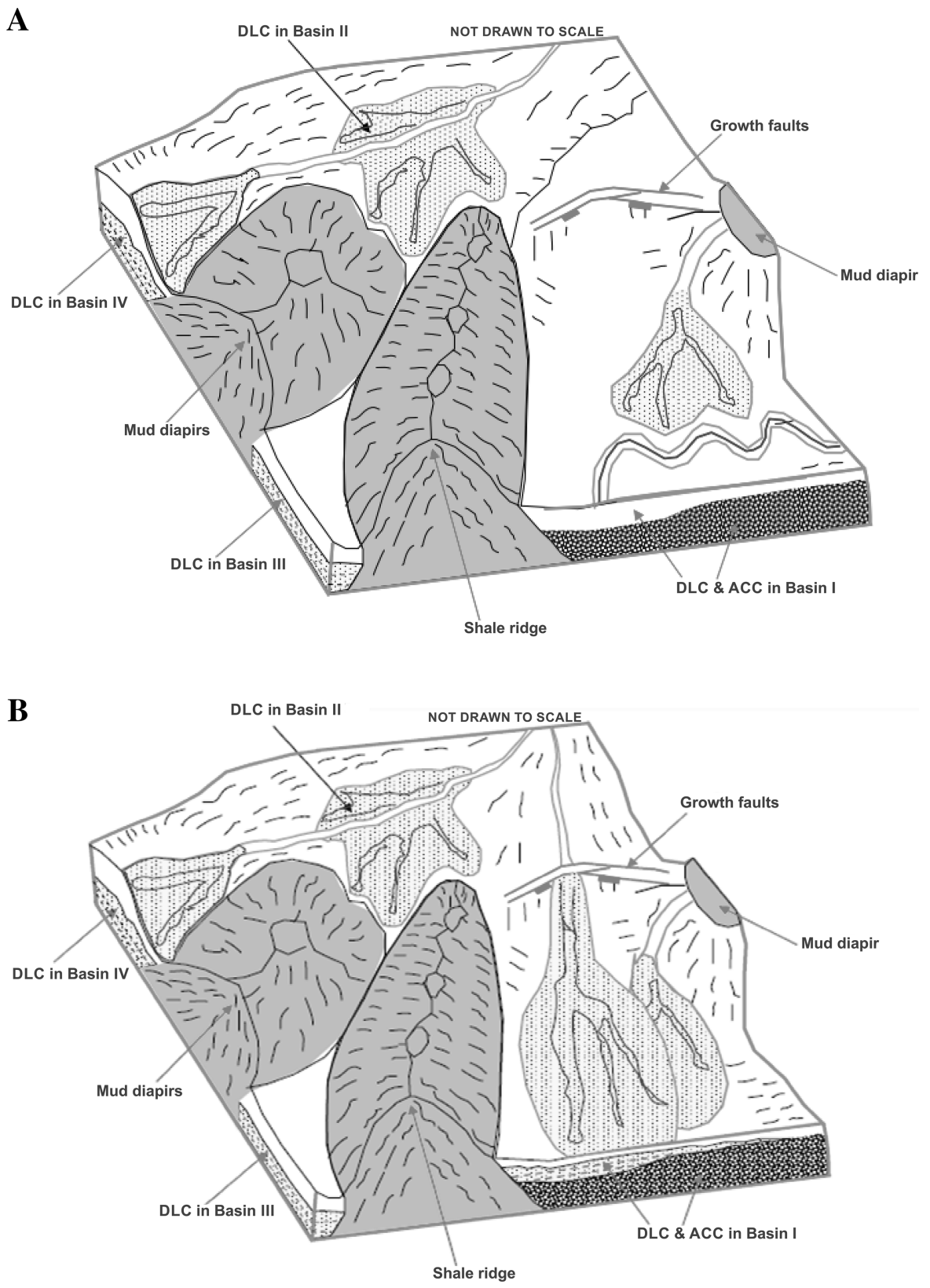

Fig. 11 a Idealized diagram of deflect stage (I) of depositional model of deepwater Niger delta. b Idealized diagram of deflect stage (II) of depositional model of deepwater Niger delta

followed by a filling to the spill point but at a different location than directly downslope across the mud diapir. At this point, the channel found a point of low resistance and deflected to go around the mud diapirs. This is a modification to the fill and spill model for the bowl-shaped salt-withdrawal basins. 


\subsection{Channel elements}

The channel elements identified are meander loop cut-off and overbank deposits, lateral accretionary channel deposits, and vertical accretionary channel deposits. Each of these is described in more details below.

\subsubsection{Meander loop cut-off and overbank deposits}

Based on seismic characteristics, these deposits are interpreted to consist of relatively coarser-grained sediments than the fans. These deposits are found within the meander loop cut-off that was eventually filled with sand-sized sediments, and the overbank of channels. These deposits can extend for up to $1000 \mathrm{~m}$ laterally (Fig. 12a). Using thickness and lateral extent, meander loop and overbank deposits are relatively small in size. In a sandy depositional environment such as the study area, this facies can form important reservoir targets.

A

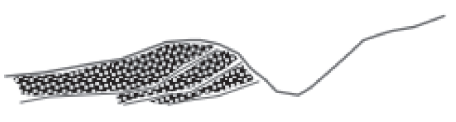

$0 \quad 2 \mathrm{~km}$
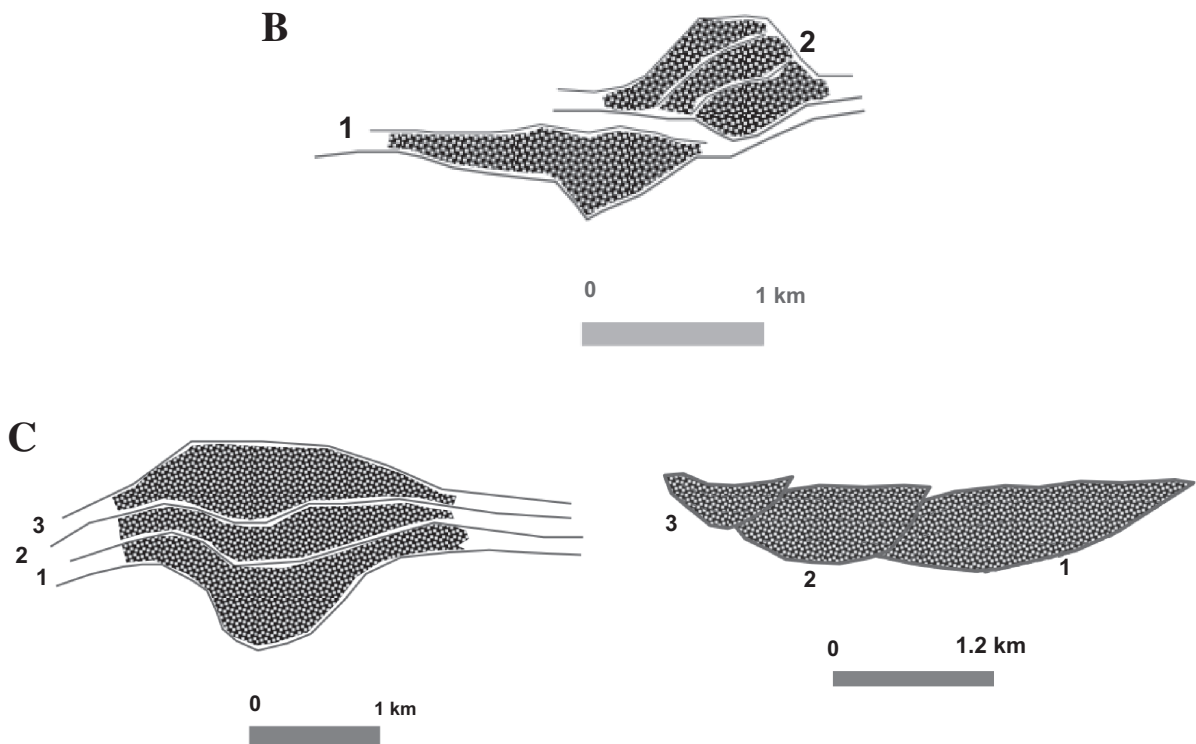

Fig. 12 a Meander loop cut off and overbank deposits. b Lateral accretion deposits. c Vertical accretion deposits 


\subsubsection{Lateral accretionary channel deposits}

These deposits formed as a result of channels frequently changing their positions due to high sediment volume. These sediments were deposited within the channel axes before they were abandoned for areas of lower elevation. These channel deposits are laterally amalgamated (Fig. 12b) and could form major reservoir targets in a sandy system such as the study area. Using both thickness and lateral extent, lateral accretion deposits are the second largest (volumetrically) of channel reservoir deposits. Also, if there is communication between the individual component channel deposits, relatively large reservoirs greater than $1000 \mathrm{~m}$ in areal extent can result. A single well with limited perforations can be used to produce such reservoirs.

\subsubsection{Vertical accretionary channel deposits}

This is similar to lateral accretionary channel deposits in that it consists of amalgamated channel deposits. The difference, however, is that vertical accretionary channel deposits are made up of individual channels vertically stacked on top of each other (Fig. 12c). Using thickness and lateral extent, the vertically stacked channel deposits are volumetrically the largest of all channel deposits. When formed in a very sandy system like the study area, such deposits can result in a major reservoir with lateral extent up to $1000 \mathrm{~m}$ and hundreds of meters in thickness.

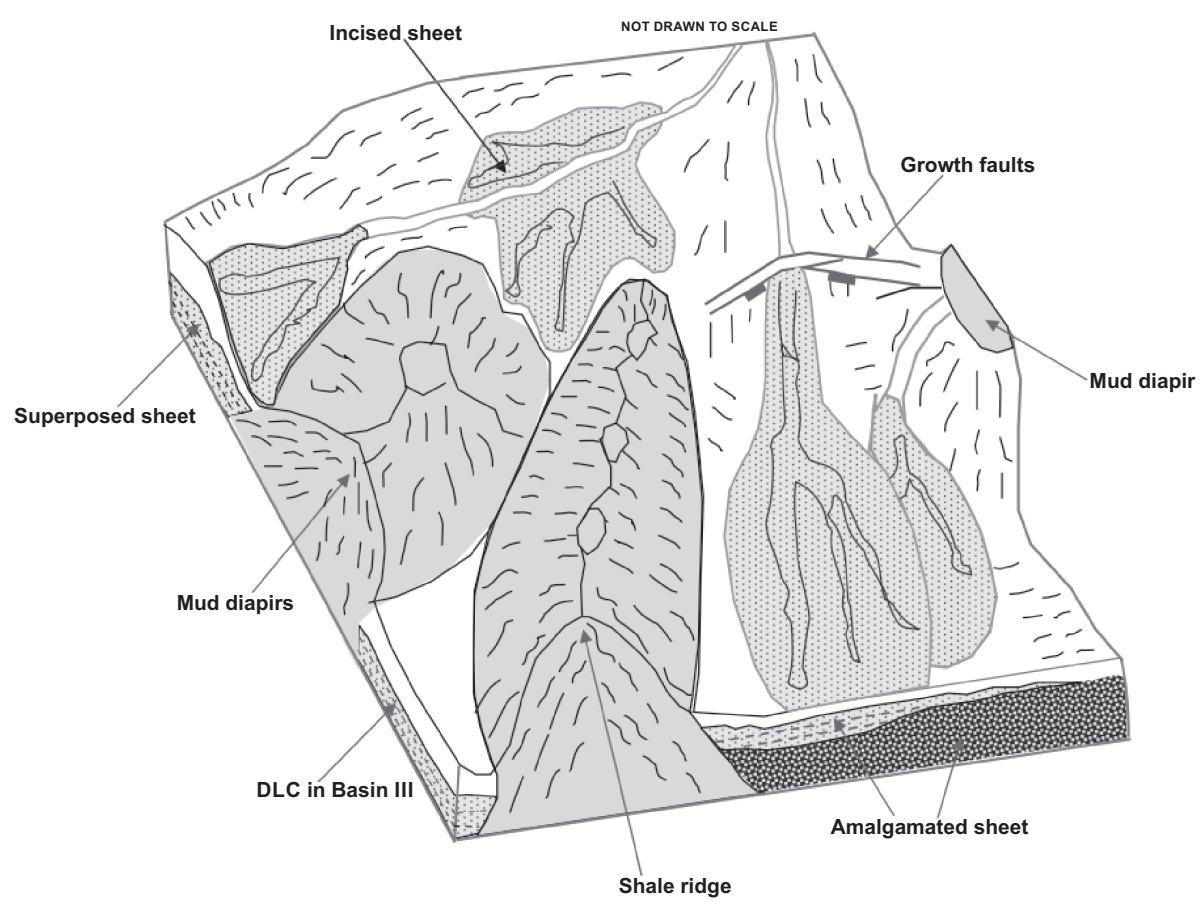

Fig. 13 Idealized diagram of offshore Niger delta showing different reservoir sheet elements 


\subsection{Sheet elements}

Sheet elements identified in the study area are incised sheets, amalgamated sheets, and superposed sheets (Fig. 13). Each of these is described in more detail below.

\subsubsection{Incised sheets}

These are sheets elements that have been incised by younger channels such as the partially confined fan in Basin II of the study area. This has production significance because if the younger channel is ultimately filled with shale, it creates baffles between the two sides of the fan and thus prevents communication between either side of the fan. As a result, a different development plan must be used to exploit or produce fluid from either side of the fan.

\subsubsection{Amalgamated sheets}

These are sheet elements that formed from different channels such as in Basin I in the study area. The fan in the southeast portion is derived from the EW flowing channel, the channel flowing from the top of the eastern diapir, as well as from the youngest N-S channel. These channels all deposited fans in Basin I. If the fans are not separated by baffles, this could result in a major reservoir with great lateral and vertical extent.

\subsubsection{Superposed sheets}

Superposed sheets resulted from continuous deposition of younger fans on top of old ones by channels after the flow encountered a reduction in slope gradient, such as in Basins III and IV in the study area. Superposed sheets could be very good reservoir targets because they are made up of vertically stacked fans that can be accessed by a single vertical well. Even if there are baffles between the individual fans, several perforations from a single well will solve the problem.

\section{Conclusions}

The following conclusions are drawn:

1. Amalgamated or accretionary channel complexes (ACCs), distributary channel and lobe complexes (DLCs), and drape complexes (DCs) are types of seismic facies recognized in the offshore Niger Delta area. ACCs can be distinguished from DLCs by their seismic characteristics in that, while ACCs generally consist of high-impedance, discontinuous, and chaotic seismic reflections, DLCs are made up of continuous, highimpedance, layered seismic reflections. ACC is another reservoir facies type that could be a good exploration target.

2. Channels vary in both morphology and associated depositional elements. Channel sinuosity was found to generally reduce with decreasing age of occurrence. The more sinuous and older channels had reservoir facies deposited both within their axes as well as lobes. The less sinuous and younger channels only had reservoir facies deposited as lobes, because their channels were narrow and incising. Knowledge of 
channel architectural variation will give an idea of the type of deposit to anticipate within each slope channel.

3. Six different types of reservoir elements were identified in the study area. Three reservoir elements associated with the channel axis are: (1) meander loop fill and overbank deposits, (2) lateral accretionary channel deposits, and (3) vertical accretionary channel deposits. Each of these varies greatly from the other in its architectural characteristics. Also, three reservoir elements that vary in their architecture were associated with sheet deposits. They are: (1) incised sheets, (2) superposed sheets, and (3) amalgamated sheets. Knowledge of these variations as well as identification of the different elements is necessary to a successful exploration and development plan.

4. The depositional model generated for the study area, and for any similar intra-slope basins where mud diapirs provide the structural control, shows repeatable and cyclic depositional processes involved in sedimentation in this type of basin. The ideal major depositional cycle is made up of mass transport deposits at the base, overlain by a distributary channel and lobe complex, overlain by an amalgamated channel complex, and capped by a drape complex. A mega depositional cycle is made up of two or more major depositional cycles.

Acknowledgments The authors would like to acknowledge the management of Kumasi Polytechnic, Kumasi headed by the Rector Prof. N.N.N. Nsowah-Nuamah, for providing financial assistance to undertake this study. Special thanks to oil \& gas resource and digital Geo-Processes, Yangtze University and Research Institute of China National Offshore Oil Corporation for providing data to undertake the research.

\section{References}

Adeogba AA, McHargue TR, Graham SA (2005) Transient fan architecture and depositional controls from near-surface 3-D seismic data, Niger delta continental slope. AAPG Bull 89:627-643

Badalini G, Kneller B, Winker CD (2000) Architecture and processes in the late Pleistocene Brazos-Trinity turbidite system, Gulf of Mexico continental slope. In: Weimer P, Slatt RM, Coleman J, Rosen, Nelson H, Bouma AH, Styzen MJ, Lawrence DT (eds), Deep-water reservoirs of the world: Gulf Coast Society of Economic Paleontologists and Mineralogists Foundation, 20th annual research conference, pp 16-34

Beaubouef RT, Friedmann SJ (1998) High-resolution seismic/sequence stratigraphy of intra-slope basins, western Gulf of Mexico (abs.): extended abstracts volume, AAPG international conference, pp 404-405

Beaubouef RT, Friedmann SJ (2000) High-resolution seismic/sequence stratigraphic framework for the evolution of Pleistocene intra slope basins, Western Gulf of Mexico: depositional models and reservoir analogs. In: Weimer P, Slatt RM, Coleman J, Rosen NC, Nelson H, Bouma AH, Styzen MJ, Lawrence DT (eds), Deep-water reservoirs of the world: Gulf Coast Society of Economic Paleontologists and Mineralogists Foundation, 20th annual research conference, pp 40-60

Booth JR, DuVernay III AE, Pfeiffer SS, Styzen MJ (2000) Sequence stratigraphic framework, depositional models, and stacking patterns in the Auger Basin: Central Gulf of Mexico. In: Weimer P, Slatt RM, Coleman J, Rosen NC, Nelson H, Bouma AH, Styzen MJ, Lawrence DT (eds) Deep-water reservoirs of the world: Gulf Coast Society of Economic Paleontologists and Mineralogists Foundation, 20th annual research conference, pp 82-103

Brami TR, Pirmez C, Archie C, Holman KL (2000) Late Pleistocene deepwater stratigraphy and depositional processes, offshore Trinidad and Tobago. In: Weimer P, Slatt RM, Coleman J, Rosen NC, Nelson H, Bouma AH, Styzen MJ, Lawrence DT (eds), Deep-water reservoirs of the world: Gulf Coast Society of Economic Paleontologists and Mineralogists Foundation, 20th annual research conference, pp 104-115

Clark JD, Pickering KT (1996) Architectural elements and growth patterns of submarine channels: application to hydrocarbon exploration. AAPG Bull 80:194-221 
Corredor F, Shaw JH, Bilotti F (2005) Structural styles in the deep-water fold and thrust belts of the Niger delta. AAPG Bull 89:753-780

Damuth JE (1994) Neogene gravity tectonics and depositional processes on the deep Niger delta continental margin. Mar Pet Geol 11(3):320-346

Demyttenaere R, Tromp JP, Ibrahim A, Allman-Ward P, Meckel T (2000) Brunei deep water exploration: from sea floor images and shallow seismic analogues to depositional models in a slope turbidite setting. In: Weimer P, Slatt RM, Coleman J, Rosen NC, Nelson H, Bouma AH, Styzen MJ, Lawrence DT (eds), Deep-water reservoirs of the world: Gulf Coast Society of Economic Paleontologists and Mineralogists Foundation, 20th annual research conference, pp 304-317

Doust H, Omatsola E (1990) Niger delta. In: Edwards JD, Santagrossi PA, Edwards JD, Santagrossi PA (eds) Divergent/passive margin basins, vol 48. AAPG Memoir, Tulsa, pp 201-238

Edith M, Fugelli G, Olsen TR (2005) Risk assessment and play fairway analysis in frontier basins: Part $1 \&$ 2-examples from Offshore Mid-Norway. AAPG Bull 89:883-896

Evamy BD, Haremboure J, Kamerling P, Knaap WA, Molloy FA, Rowlands PH (1978) Hydrocarbon habitat of Tertiary Niger Delta. Am Assoc Pet Geol Bull 62:277-298

Galloway WE (1975) Process framework for describing the morphologic and stratigraphic evolution of deltaic depositional systems. In: Broussard ML (ed) Deltas, models for exploration. Geological Society, Houston, pp 87-98

Gardner MH, Borer JM, Melick JJ, Mavilla N, Dechesne M, Wagerle RN (2003) Stratigraphic processresponse model for submarine channels and related features from studies of Permian Brushy Canyon outcrops, West Texas. Mar Pet Geol 20:757-787

Graue K (2000) Mud volcanoes in deepwater Nigeria. Mar Pet 17:959-974

Hospers J (1965) Gravity field and structure of the Niger delta, Nigeria, West Africa. GSA Bull 74:1-12

Knox GJ, Omatsola EM (1989) Development of the Cenozoic Niger delta in terms of the "Escalator Regression" model and impact on hydrocarbon distribution. In: Proceedings KNGMG symposium "Coastal Lowlands, Geology and Geotechnology," Dordrecht, Kluwer, pp 181-202

Kulke H (1995) Nigeria. In: Kulke H (ed) Regional petroleum geology of the world, Part II: Africa, America, Australia and Antarctica. Gebruder Borntaeger, Berlin, pp 143-172

Lehner P, De Ruiter PAC (1977) Structural history of Atlantic Margin of Africa. Am Assoc Pet Geol Bull 61:961-981

Mayall M (2000) The architecture of turbidite slope channels. In: Weimer P, Slatt RM, Coleman J, Rosen NC, Nelson H, Bouma AH, Styzen MJ, Lawrence DT (eds), Deep-water reservoirs of the world: Gulf Coast Society of the Society of Economic Paleontologists and Mineralogists Foundation, 20th annual research conference, pp 578-586

McHargue TR (1991) Seismic facies, processes, and evolution of Miocene inner fan channels, Indus submarine fan. In: Weimer P, Link MH (eds) Seismic facies and sedimentary processes of modern and ancient submarine fans and turbidite systems. Springer-Verlag, Berlin, pp 403-413

Mitchum RM, Jr, Sangree JB, Vail PR, Wornardt WW (1991) Sequence stratigraphy in the late Cenozoic expanded sections, Gulf of Mexico. In: Armentrout JM, Perkins BF (eds), Sequence stratigraphy as an exploration tool, concepts and practices in the Gulf Coast: Gulf Coast Section, SEPM Foundation, eleventh annual research conference, pp 237-256

Morley CK, Guerin G (1996) Comparison of gravity-driven deformation styles and behaviour associated with mobile shales and salt. Tectonics 15(6):1154-1170

Pirmez C, Beaubouef RT, Friedmann SJ, Mohrig DC (2000) Equilibrium profile and base level in submarine channels: examples from Late Pleistocene systems and implications for the architecture of deep-water reservoirs. In: Weimer P, Slatt RM, Coleman J, Rosen NC, Nelson H, Bouma AH, Styzen MJ, Lawrence DT (eds), Deep-water reservoirs of the world: Gulf Coast Society of the Society of Economic Paleontologists and Mineralogists Foundation, 20th annual research conference, pp 782-805

Posamentier HW, Kolla V (2003) Seismic geomorphology and stratigraphy of depositional elements in deep-water settings. J Sediment Res 73(3):367-388

Posamentier H, Meizarwin W, Wisman PS, Plawman T (2000) Deep-water depositional systems, Ultra-deep Makassar Strait, Indonesia. In: Weimer P, Slatt RM, Coleman J, Rosen NC, Nelson H, Bouma AH, Styzen MJ, Lawrence D. T (ed), Deep-water reservoirs of the world: Gulf Coast Society of the Society of Economic Paleontologists and Mineralogists Foundation, 20th annual research conference, pp 806-816

Prather BE, Booth JR, Steffens GS, Craig PA (1998) Classification, lithologic calibration, and stratigraphic succession of seismic facies of intraslope basins, deep-water Gulf of Mexico. AAPG Bull 82:701-728

Short KC, Stauble AJ (1967) Outline of geology of Niger delta. AAPG Bull 51:761-799

Stacher P (1995) Present understanding of the Niger delta hydrocarbon habitat. In: Oti MN, Postma G (eds) Geology of deltas. A. A. Balkema, Rotterdam, pp 257-267 
Sullivan MD, Jensen G, Goulding F, Jeneette D, Foreman L, Stern D (2000) Architectural analysis of deepwater outcrops: implications for exploration and development of the Diana sub-basin, Western Gulf of Mexico. In: Weimer P, Slatt RM, Coleman J, Rosen NC, Nelson H, Bouma AH, Styzen MJ, Lawrence DT (eds), Deep-water reservoirs of the world: Gulf Coast Society of the Society of Economic Paleontologists and Mineralogists Foundation, 20th annual research conference, pp 1010-1031

Weimer P, Slatt RM (2004) Petroleum systems of deepwater settings, distinguished instructor series, No. 7, Society of Exploration Geophysicists and European Association of Geoscientists and Engineers, p. 1-1 to 9-75

Weimer P, Varnai P, Acosta ZM, Budhijanto FM, Martinez RE, Navarro AF, Rowan MG, McBride BC, Villamil R (1995) Sequence stratigraphy of Neogene turbidite systems, northern Green Canyon and Ewing Bank, northern Gulf of Mexico (abs.): AAPG annual meeting program with abstracts, p 103A Xiao H, Suppe J (1992) Origin of rollover. Am Assoc Pet Geol Bull 76:509-529 